\title{
Plexiform Schwannoma
}

National Cancer Institute

\section{Source}

National Cancer Institute. Plexiform Schwannoma. NCI Thesaurus. Code C6969.

A schwannoma characterized by a plexiform or multinodular growth pattern. It usually arises from the skin or subcutaneous tissues in the extremities, trunk, and head and neck. 